winged petioles, one foot to thirteen inches long and about two inches broad, with five faint longitudinal veins on each side of the midrib, sprinkled with black dots and close adpressed hairs of white color. Midrib produced six or seven inches beyond the lamina, not curled but shortly recurved and bearing ${ }^{\circ}$ an ascidium three to four inches long, inflated at the base, the two anterior ribs winged with wings $1 \frac{1}{2}$ to 2 lines broad, colored and prominently ciliate towards the truncate top, posterior wing somewhat faint, ending in a hooked spur. Operculum ovate, with numerous small reddish glands on the inner side. Peristome narrow and slender, marked with close, transverse lines.

Habitat, Cape York, whence it was sent by a correspondent some few years ago to the Queensland Acclimatization Society.

\title{
On a Fossiliferous Bed at the Mouth of the Endeavour RIVER.
}

By the Rev. J. E. Tenison-Woods, F.G.S., F.L.S., President of the Linnean Society, N.S.W.

The mouth of the Endeavour River is a wide estuary forming a bay which is entered by crossing a sandy bar. The north side of the entrance is a flat sandy beach. The south side is a granite hill about 900 feet high. On the land side this granite hill is broken through by a volcanic dyke, very like some of the older tertiary dolerites of Victoria and New South Wales. The granite hill is called Grassy Hill, and it was upon this which Captain Cook encamped while repairing the "Endeavour," more than a hundred years ago. It is very steep on the side facing the sea, but in front of it inside the bar there is a mass of large boulders derived from the volcanic dyke. These are covered with the usual littoral shell-fish of these latitudes, namely Planaxis sulcata, Nerita polita, Nerita albicella, Acmaa marmorata, \&c. The shingle round these boulders is much mingled with sand and tropical 
shells, and occasional fragments of coral. The latter is much worn and broken, and is evidently derived from some of the reefs, the nearest of which is about eight miles away. The township of Cooktown is built on the slopes of Grassy Hill at less than a mile inside the bar, where the volcanic dyke ceases and where the hill is less steep. Some short time since the corporation had occasion to make some excavations at the foot of the hill and not very far from the volcanic dyke. At a depth of ten feet a deposit of coral debris was reached, consisting of broken fragments such as we only meet now very close to a coral reef or at its surface. It was of entirely a different nature from the shingle now being deposited around the trap boulders.

I examined the debris carefully, and found it consisted of existing species of Madrepora, Fungia, Turbinaria, Pavonia, Seriatopora, Favia, Pocillopora, Solenastraa, Galaxea, Mussa, \&c. I could not trace any difference either in the size or character of the fossils, but some of the species are more common than those of the neighbouring reefs. The fragments were not much rolled as coral usually is when it forms shingle beds. It was stained a reddish colour, no doubt derived from the alluvium above it, which was derived from the decomposed trap. The level of the deposit was about three or four feet above the present water level and about a dozen yards from where the waters now reach. There is no living coral growing anywhere near these beds, the nearest reef from which the formation has been derived must have been near, and all traces of it have now disappeared. There must have been also some alteration in the levels, probably upheaval, though it is but slight. We cannot easily suppose that the bed of the estuary has shifted. The fresh-water stream connected with it, that is to say the Endeavour River and its tributaries is too insignificant to effect the formation of the estuary. At present I do not see any way of accounting for the deposit, except by upheaval and the consequent destruction of the coral. The fact is of great importance, because if established it is the only instance 
of a raised beach which has hitherto been recorded on the whole of the north-east coast of Australia. I cannot give any idea of the extent of the beds. They had been partly covered over at the time of my visit. The coral had been found so useful as road metal and for lime-burning purposes, that the material was removed in large quantities, This was causing considerable injury to the roads and wharves, so the government ordered the quarries to be filled in. The beds are of course recent, but from the thickness of the alluvium which covered them they must be of considerable antiquity. We have reasonable ground for supposing that some changes have taken place even since Captain Cook's time. He relates having found an abundance of turtle on an island reef which is known now as the turtle reef. A portion of it used to be always uncovered, but now it is only at low water springs that any of the reef is laid bare, and it is consequently quite abandoned by turtles. They only frequented the locality for the purpose of laying their eggs, for which they choose dry sandy places.

Another circumstance worthy of mention is that immense patches of floating pumice, are met with at times inside the Barrier Reef. They are with marine animals and exuviæ of all kinds, but especially the internal skeleton of a species of Sepia. This pumice from its appearance must have been a long time in the water. It need hardly be added that it could not have come from any part of Australia. It may be connected with some of more recent volcanic outbreaks of the Pacific Islands. Fragments of the same stone are frequently found in the shingle and sands on the beaches of the whole of north-east Australia. I looked very carefully among the coral debris of the formation here described, but could not find any traces of pumice or volcanic stone. 


\section{$2 \mathrm{BHL}$ Biodiversity Heritage Library}

Woods, Julian Tenison. 1880. "On a fossiliferous bed at the mouth of the Endeavour River." Proceedings of the Linnean Society of New South Wales 5, 187-189. https://doi.org/10.5962/bhl.part.15876.

View This Item Online: https://www.biodiversitylibrary.org/item/30231

DOI: https://doi.org/10.5962/bhl.part.15876

Permalink: https://www.biodiversitylibrary.org/partpdf/15876

\section{Holding Institution}

MBLWHOI Library

\section{Sponsored by}

MBLWHOI Library

\section{Copyright \& Reuse}

Copyright Status: NOT_IN_COPYRIGHT

This document was created from content at the Biodiversity Heritage Library, the world's largest open access digital library for biodiversity literature and archives. Visit BHL at https://www.biodiversitylibrary.org. 